\title{
NATURE AND THE ARTS IN EARLY MODERN NAPLES
}


NATURB I LDER

IMAGES OF NATURE

Herausgegeben von

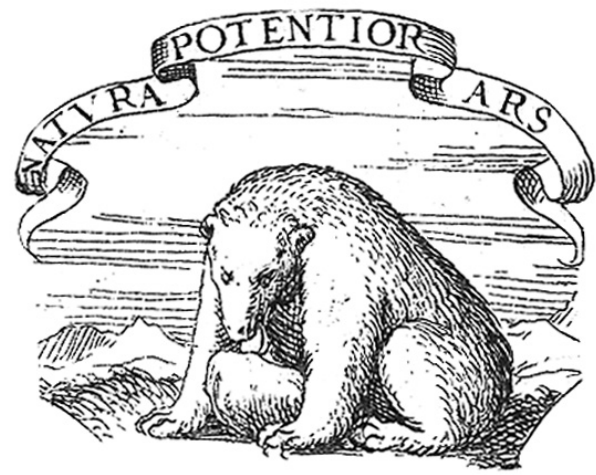

Frank Fehrenbach, Robert Felfe und Iris Wenderholm

BAND 7 


\section{NATURE AND THE ARTS IN EARLY MODERN NAPLES}

Edited by

Frank Fehrenbach and Joris van Gastel 
Gedruckt mit großzügiger Unterstützung durch die Alexander von Humboldt-Stiftung und die Fritz Thyssen-Stiftung.

ISBN 978-3-11-059922-0

eISBN (PDF) 978-3-11-072048-8

ISSN 2367-1955

Library of Congress Control Number: 2020943498

Bibliographic information published by the Deutsche Nationalbibliothek

The Deutsche Nationalbibliothek lists this publication in the Deutsche Nationalbibliographie; detailed bibliographic data are available on the internet at http://dnb.dnb.de

(C) 2020 Walter De Gruyter GmbH, Berlin/Boston

Cover illustration: Luca Giordano and Giuseppe Recco: The Riches of the Sea with Neptune, Tritons and Two Nereids, 1684, oil on canvas, $234.5 \times 296 \mathrm{~cm}$, Adelaide, Art Gallery of South Australia (detail).

Layout and typesetting: P. Florath, Stralsund

Printing and binding: DZA Druckerei zu Altenburg GmbH, Altenburg

www.degruyter.com 